\title{
In Situ Immunoassay for Detection of Citrus tristeza virus
}

\author{
Youjian Lin, Department of Plant Protection, Fujian Agricultural University, Fuzhou, Fujian 350002, P. R. China; \\ Phyllis A. Rundell, Indian River Research and Education Center, University of Florida, Fort Pierce 34945; \\ Lianhui Xie, Department of Plant Protection, Fujian Agricultural University, Fuzhou, Fujian 350002, P. R. China; \\ and Charles A. Powell, Indian River Research and Education Center, University of Florida, Fort Pierce 34945
}

\begin{abstract}
Lin, Y., Rundell, P. A., Xie, L., and Powell, C. A. 2000. In situ immunoassay for detection of Citrus tristeza virus. Plant Dis. 84:937-940.

An in situ immunoassay (ISIA) is described for detection of Citrus tristeza virus (CTV). Sections from stems, petioles, or leaf veins of citrus plants that were healthy or infected with CTV were fixed with $70 \%$ ethanol and incubated with specific polyclonal antiserum (PCA) 1212 or with monoclonal antibodies (MAbs) MCA13 or $17 \mathrm{G} 11$. Bound antibodies were labeled with enzyme-conjugated species-specific secondary antibodies and exposed to a substrate mixture (nitroblue tetrazolium and 5-bromo-4-chloro-3-indolyl phosphate). Presence of CTV antigens was indicated by the development of a purple color, which could be visualized by light microscopy, in the phloem tissues of infected citrus plants. No purple color was observed in the phloem tissues of healthy plants. All isolates used in this study, both severe and mild, were detected by ISIA with the PCA 1212 and the broad spectrum MAb 17G11, but only severe isolates were detected by the strain selective MAb MCA13. Location of CTV antigens could be determined directly and accurately by ISIA in both fresh tissues and samples stored in plastic bags at $4^{\circ} \mathrm{C}$ or frozen for 4 weeks. Sensitivity of ISIA for detecting CTV in infected plants compared favorably with that of direct tissue blot immunoassay (DTBIA). ISIA is a simple, rapid, specific, and practical procedure for CTV identification applicable to both research and diagnostic needs.
\end{abstract}

Additional keywords: diagnosis, serology

Citrus tristeza virus (CTV) causes the most serious viral disease of citrus worldwide (1). The virus has flexuous threadlike particles $2,000 \mathrm{~nm}$ in length and $11 \mathrm{~nm}$ in diameter (1). CTV infection causes a diverse range of symptoms in citrus depending on the host and virus isolates. The most common, economically important symptoms are decline or death of trees grafted on sour orange rootstock and/or stem pitting of the scion irrespective of the rootstock. Some strains of CTV produce mild symptoms only in Mexican lime and do not cause decline or stem pitting (13).

Early detection of CTV in budwood sources is one of the most effective control strategies for CTV. Many efforts have been made to find better methods to detect CTV $(1,6,7,13,14,17)$. Use of enzyme-labeled antibodies in serological assays has pro-

Corresponding author: Charles A. Powell

E-mail: capo@gnv.ifas.ufl.edu

Florida Agricultural Experiment Station Journal Series R-07125.

Accepted for publication 24 May 2000.

Publication no. D-2000-0705-01R

(c) 2000 The American Phytopathological Society vided diagnostic probes with a high level of sensitivity, stability, low cost, and safety for detection and identification of CTV $(2,7,14)$. A number of different serological methods have been developed for detecting CTV. They include sodium dodecyl sulfate (SDS)-immunodiffusion $(2,3,6)$, serologically specific electron microscopy (SSEM) (3), SSEM-gold labeled assay (3), enzymelinked immunosorbent assay (ELISA) $(1,2,5,12,14,16)$, radioimmunosorbent assay (RISA) (14), in situ immunofluorescence (ISIF) (4), Western blot assay $(8,9,14)$, dotimmunobinding assay $(15,16)$, and direct tissue blot immunoassay (DTBIA) (7). Recently, bacterially expressed coat protein fragments have been used to produce CTVspecific antibodies (11), and strain-specific serological assays to diagnose CTV infection have been developed $(10,11,13,18)$. Except for ISIF, these procedures cannot directly detect CTV within the infected plants (14). However, ISIF needed fluorescent dye and fluorescence microscopy, and occasionally it gave false positives because host components fluoresced with the use of some dyes $(4,14)$.

This paper describes an ISIA for directly detecting CTV without use of fluorescent dyes. It is a simple and specific procedure that detects CTV in infected citrus plants in about $2 \mathrm{~h}$, and the most costly equipment needed was a light microscope.

\section{MATERIALS AND METHODS}

Virus isolates and plant materials. Six isolates of CTV, maintained in a quarantine greenhouse at the Indian River Research and Education Center, Fort Pierce, FL, were used in this study. The T-36 isolate, described earlier $(4,17)$, is a severe isolate causing veinclearing, stunting, and stem pitting on Mexican lime (Citrus aurantifolia (Christm.) Swingle), mild seedling yellows (SY) symptoms on Eureka lemon (C. limon (L.) Burm. f.) and sour orange seedlings, and a decline reaction in sweet orange trees on sour orange rootstock. Isolates T-30, T-26, and T-4, described by Rosner et al. (17), are mild isolates. T-30 and T-26 cause mild symptoms on Mexican lime, but no SY or decline symptoms on sour orange rootstock. Isolate $\mathrm{T}-4$ causes strong veinclearing in Mexican lime, no visible decline in sweet orange on sour orange rootstock, and no SY symptoms $(4,6,17)$. Isolate $\mathrm{T}-3$, another severe isolate, causes severe symptoms on Mexican lime, a decline reaction in sweet orange on sour orange rootstock, and SY symptoms on Eureka lemon and sour orange seedlings $(4,6,17)$. Isolate MM2 was obtained by budding sources of T-36, T-30, $\mathrm{T}-26, \mathrm{~T}-4$, and $\mathrm{T}-3$ together into a Mexican lime seedling.

Stems, petioles, and leaf veins of young new shoots or mature shoots of citrus plants, either infected with CTV or healthy, were used for ISIA experiments and DTBIA tests. Main leaf veins and petioles of young new shoots were used to prepare extractions for ELISA experiments.

Antisera. One polyclonal antiserum (PCA), 1212, and two monoclonal antibodies (MAbs), 17G11 and MCA13, were compared. The PCA 1212 was generated in rabbits against purified virions of an Australian CTV isolate causing stem pitting in orange (S. M. Garnsey, personal communication) and was kindly provided by S. M. Garnsey. The IgG from PCA 1212 was used $(1 \mu \mathrm{g} / \mathrm{ml})$ for coating the wells of microtiter plates for ELISA and for reacting with antigens of CTV in ISIA. The CTV-MAb 17G11 was generated against the virions of both the T36 isolate and the 
B185 isolate. It is reactive to most isolates of CTV and is specific to an epitope in the intact CTV coat protein. The MCA13 was generated against severe CTV isolate T36 and was described earlier (13). Thus, MCA13 reacts with most severe sources of CTV but does not react with mild isolates from Florida $(7,13)$. The $17 \mathrm{G} 11$ or MCA13 was used as the second (detecting) antibody in ELISA and the primary antibody in ISIA and DTBIA tests.

The labeled secondary antibodies, alkaline phosphatase conjugated goat antimouse Ig $(\mathrm{H}+\mathrm{L})$-AP and alkaline phosphatase conjugated goat antirabbit IgG, were from Southern Biotechnology Associates, Inc., Birmingham, AL, and Sigma Chemical Co., St. Louis, MO, respectively.

In situ immunoassay (ISIA). Sections 100 to $200 \mu \mathrm{m}$ thick were cut, using a new razor blade, from fresh stems, petioles, or veins from healthy or infected citrus plants. There were four to six replicates for each sample. Sections were transferred with forceps to 24-well plastic plates (Corning Glass Works, Corning, NY) and fixed with 300 to $1,000 \mu \mathrm{l}$ of $70 \%$ ethanol for 5 to 20 min at room temperature (longer exposure reduced sensitivity). After the alcohol was removed using a pipette, the sections were incubated with 300 to $500 \mu \mathrm{l}$ of specific antibodies, 17G11 (undiluted cell culture fluid), MCA13 or PCA 1212 (at $1 \mu \mathrm{g} / \mathrm{ml}$ concentration in PBST-B) for 30 to $60 \mathrm{~min}$ at $37^{\circ} \mathrm{C}$. The PBST-B contained $0.15 \mathrm{M}$ sodium chloride, $0.015 \mathrm{M}$ sodium phosphate, $\mathrm{pH} 7.0,0.05 \%$ Tween 20 , and $3 \%$ fetal bovine serum or bovine serum albumin. The sections were washed with PBST-PVP (PBST with 2\% polyvinylpyrrolidone, Ave. F. W. 40,000, Fisherbiotech, Fair Lawn, NJ) for 5 to $10 \mathrm{~min}$, and incubated with 300 to $500 \mu$ l of enzyme-labeled secondary antibodies at $37^{\circ} \mathrm{C}$ for 30 to 60 min. Alkaline phosphatase conjugated goat antimouse Ig $(\mathrm{H}+\mathrm{L})$-AP was used for sections exposed to $17 \mathrm{G} 11$ or MCA13, and alkaline phosphatase conjugated goat antirabbit $\operatorname{IgG}$ was used for sections exposed to IgG of 1212. The sections were washed again with PBST-PVP for 5 to $10 \mathrm{~min}$ and with TTBS buffer (20 mM tris (hydroxymethyl) aminomethane, $500 \mathrm{mM}$ sodium chloride, and $0.05 \%$ Tween $20, \mathrm{pH} 7.5$ ) for 5 to $10 \mathrm{~min}$. Sections were then incubated with 300 to $500 \mu \mathrm{l}$ of a freshly prepared NBT-BCIP substrate mixture (66 $\mu \mathrm{l}$ of nitroblue tetrazolium at $0.3 \mathrm{mg} / \mathrm{ml}$ and 33 $\mu \mathrm{l}$ of 5-bromo-4-chloro-3-indolyl phosphate at $0.15 \mathrm{mg} / \mathrm{ml}$, in $10 \mathrm{ml}$ of $0.1 \mathrm{M}$ sodium carbonate buffer, $\mathrm{pH} 9.8$ ) for 5 to $15 \mathrm{~min}$. After stopping the reaction by removing the substrate solution and adding 500 to $1,000 \mu \mathrm{l}$ of water to each well, the sections were transferred to a glass slice with forceps and observed under a light microscope at $\times 100$ magnification. The development of a purple color in the phloem tissue cells of citrus was considered a positive reaction. Sections in which no purple color developed were considered negative.

The purpose of using PCA 1212 in this test was to determine if different sources of CTV antibody are suitable for ISIA. Sections from the same stems of different infected source plants, severe isolate-infected plants, and mild isolate-infected plants were used in the test to compare the effects of different antibodies, PCA 1212, MAbs 17G11 and MCA13, on the detection of CTV.

To investigate the effect of storage of samples on ISIA, samples of healthy or infected citrus plants in greenhouse and field were placed in plastic bags and kept under room temperature, refrigerated $\left(4^{\circ} \mathrm{C}\right)$, or frozen $\left(-20^{\circ} \mathrm{C}\right)$ for $1,7,14,21$, and 30 days. Stored samples were tested with the ISIA using MAb 17G11.

Samples from the same young flushes of healthy and CTV-infected plants were used to compare ISIA with DTBIA and ELISA procedures using MAbs $17 \mathrm{G} 11$ and MCA13. The direct tissue blots on nitrocellulose for DTBIA were made first, and sections for ISIA were then made from the same tissues with a razor blade. The remaining tissues were used to prepare extractions for ELISA.

ELISA. Indirect double antibody sandwich (I-DAS) ELISA $(1,2,17)$ was used in this study initially to diagnose CTV-infected citrus plants and to do a comparison with ISIA. IgG of PCA 1212 was used as coating antibody. The previously described MAbs, 17G11 and MCA13, were used as intermediate antibodies. The labeled secondary antibodies were as described above. Extractions were prepared for ELISA from $0.5 \mathrm{~g}$ of leaf midveins or bark from stems with $5 \mathrm{ml}$ of $1 \times$ PBST buffer. Wells of Immulon 2 microtiter plates (Dynatech, Chantilly, VA) were coated with $100 \mu \mathrm{l}$ of PCA 1212 at $1 \mu \mathrm{g} / \mathrm{ml}$ in $0.02 \mathrm{M}$ sodium carbonate buffer ( $\mathrm{pH}$ 9.6) and incubated overnight at $4^{\circ} \mathrm{C}$. Plates were washed with PBS-PVP three times, $3 \mathrm{~min}$ each time. One hundred microliters of the sample extracts were loaded into each well. Plates were incubated for $4 \mathrm{~h}$ at $37^{\circ} \mathrm{C}$, washed with PBST-PVP three times as above, and incubated with $100 \mu \mathrm{l}$ of either undiluted cell culture fluid of MAb $17 \mathrm{G} 11$ or MCA13 at $1 \mu \mathrm{g} / \mathrm{ml}$ in PBST overnight at $4^{\circ} \mathrm{C}$. After washing with PBST three times, plates were incubated with $100 \mu \mathrm{l}$ of alkaline phosphatase conjugated goat antimouse $\mathrm{Ig}(\mathrm{H}+\mathrm{L})-\mathrm{AP}$ at a 1:2,000 dilution in PBST-PVP for $4 \mathrm{~h}$ at $37^{\circ} \mathrm{C}$, and washed with PBST-PVP three times. Substrate reactions ( $p$-nitrophenyl phosphate (Sigma) at $1 \mathrm{mg} / \mathrm{ml}$ in $0.1 \mathrm{M}$ diethanolamine buffer, $\mathrm{pH}$ 9.8) were allowed to develop at room temperature, and absorbance values (415 nm) were determined using a Bio-Rad 3550 reader (Bio-Rad Laboratories, Richmond, CA). A positive reaction, recorded as "+", was defined as an OD $415 \mathrm{~nm}$ greater than 2.5 times that of the healthy control.
DTBIA. Direct tissue blot immunoassay was a modified procedure of the methods described by Garnsey et al. (7). Tissue blots were made from stems and leaf petioles of healthy or infected citrus plants as described above. A smooth fresh cut was made with a razor blade, and the cut surface was pressed gently and evenly to the nitrocellulose membrane (Bio-Rad Laboratories, Hercules, CA). Blots were allowed to dry for 10 to $30 \mathrm{~min}$, incubated with MAb 17G11 (undiluted cell culture fluid) or MCA13 (at $1 \mu \mathrm{g} / \mathrm{ml}$ in PBST-B) for $2 \mathrm{~h}$, and rinsed with PBST buffer for 10 min. The blots were labeled with enzyme conjugate, goat antimouse $\mathrm{Ig}(\mathrm{H}+\mathrm{L})$ at a dilution recommended by the manufacturer, for 1 to $2 \mathrm{~h}$ at $37^{\circ} \mathrm{C}$, rinsed with PBST-PVP and then with TTBS, each for 10 min. Incubating the blots with freshly prepared NBT-BCIP substrate for 5 to 20 min developed the reactions. After stopping the reaction by putting the blots in water in a petri dish, the blots were observed under a light microscope at a 10 to 25 magnification. Development of area with intense purple color located at phloem tissue cells was considered a positive reaction. Blots where no purple color developed were considered negative.

\section{RESULTS}

Detection of CTV by ISIA. Under $\times 100$ magnification, purple color in phloem tissue of CTV-infected citrus plants was clearly visible. Usually, the purple color was present in different groups of phloem cells around the xylem tissues (Fig. 1A and B). Sections prepared from old stems or leaf veins of infected plants had fewer purple spots in the phloem tissues (Fig. 1B) than those from sections of young stems or leaf veins (Fig. 1A). Under $\times 400$ magnification, the purple color was seen at the internal edge of phloem cells (Fig. 1C), but it was not present in sections from healthy plants (Fig. 1D).

Distribution of CTV antigens in citrus tissues. Longitudinal and transverse sections of stems and leaf veins were made from infected plants and assayed with ISIA to investigate the distribution of CTV in the leaf veins and stems of infected plants. The CTV antigens were distributed throughout the phloem tissues of leaf veins and the young stems (Fig. 1A, B, E, and F). There were fewer positive spots in the anterior part of main leaf veins than in the middle or bottom part of the same leaf veins.

Effect of fixing treatment on ISIA. The fixing treatment was a very important step in the ISIA. When the sections were not fixed with alcohol, there was a strong background reaction in both infected and healthy tissues. The length of time sections were fixed in $70 \%$ ethanol was critical, the optimal being 5 to $20 \mathrm{~min}$; longer fixing reduced sensitivity of the test. The only 
suitable reagent for fixing sections of tissues for ISIA was $70 \%$ ethanol. Attempts to find another fixing solution, such as FAA and formaldehyde solution, were unsuccessful.
Comparison of different antibodies. All antibody sources used in this study were suitable for detecting CTV with ISIA. PCA 1212 and MAb 17G11 detected all 40 of 40 samples infected with severe or mild isolates. The CTV MAb MCA13 detected only the severe T-3 and T-36 CTV isolates in ISIA. Those results are the same as those with ELISA and DTBIA. When the PCA 1212 and MAb MCA13 were diluted
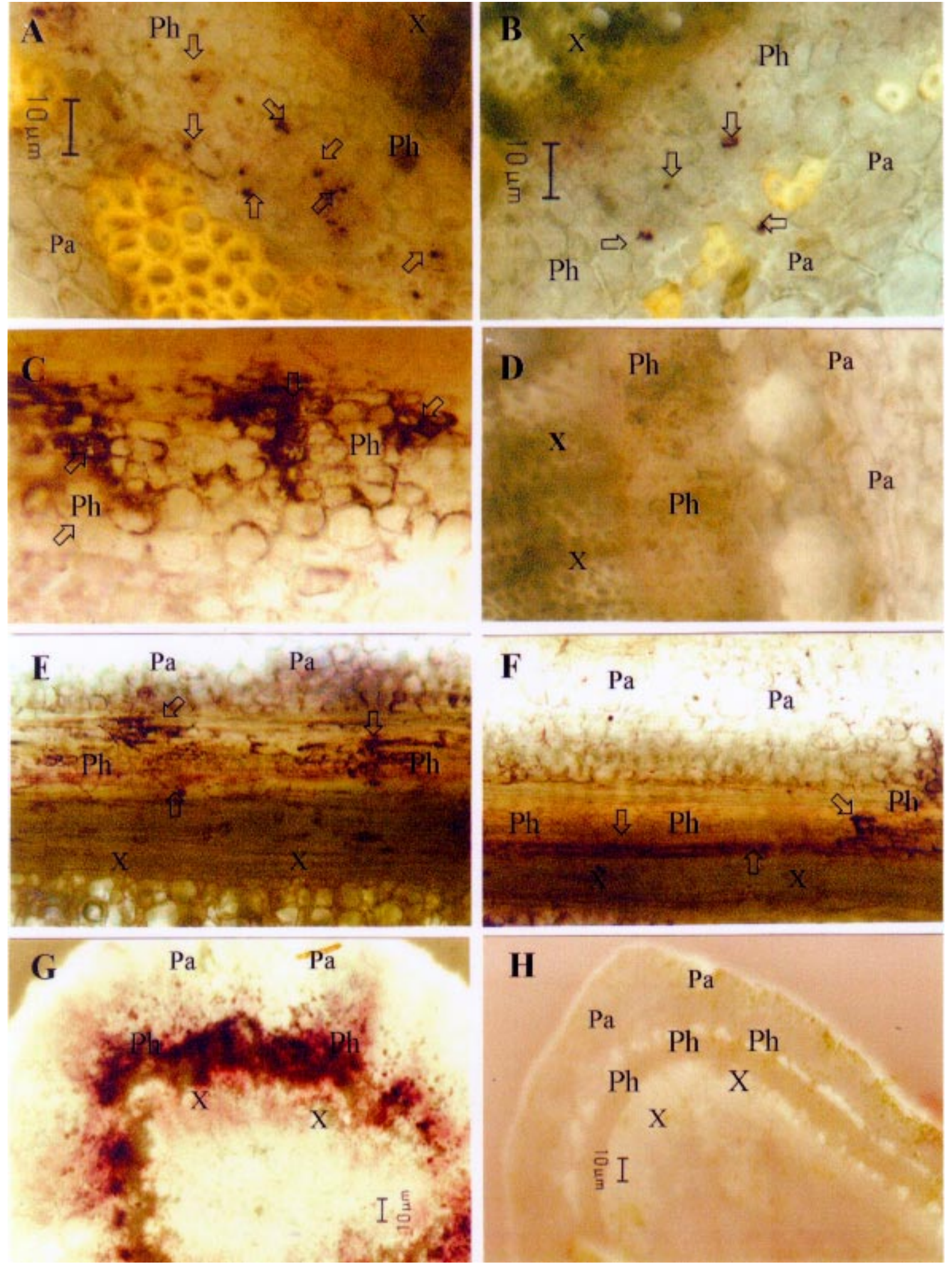

Fig. 1. In situ immunoassay (ISIA) and direct tissue blot immunoassay (DTBIA) to detect Citrus tristeza virus (CTV). (A) Transverse section of stems of infected plants in ISIA showing purple color reaction spots (arrows) in phloem tissues. (B) Transverse section of an old infected stem in ISIA showing a few reaction spots (arrows) in phloem tissues. (C) Close-up of the reaction (arrows) of CTV with antibodies in cells of citrus phloem tissues in ISIA $(\times 400)$. (D) Sections of stems of healthy citrus plants in ISIA $(\times 200)$. (E, F) Longitudinal sections of stems of infected plants in ISIA $(\times 100)$ showing distribution of CTV (arrows) in the phloem tissues of CTV-infected plants. (G) Blots of stems of infected citrus plants in DTBIA showing purple color reactions (arrows). (H) Blots of stems of healthy citrus plants in DTBIA. X: xylem tissues; Pa: parenchyma tissues; Ph: phloem tissues. 
Table 1. Comparison of enzyme-linked immunosorbent assay (ELISA), direct tissue blot immunoassay (DTBIA), and in situ immunoassay (ISIA) for detection of different isolates of Citrus tristeza virus (CTV) with CTV strain-specific antibodies ${ }^{\mathrm{a}}$

\begin{tabular}{|c|c|c|c|c|c|c|c|}
\hline \multirow[b]{2}{*}{ Isolate } & \multicolumn{3}{|c|}{ MCA13 } & \multicolumn{3}{|c|}{$17 G 11$} & \multirow[b]{2}{*}{ Bioassay $^{b}$} \\
\hline & ELISA & DTBIA & ISIA & ELISA & DTBIA & ISIA & \\
\hline T-36 & + & + & + & + & + & + & S \\
\hline T-3 & + & + & + & + & + & + & $\mathrm{S}$ \\
\hline T-30 & - & - & - & + & + & + & M \\
\hline T-26 & - & - & - & + & + & + & M \\
\hline T-4 & - & - & - & + & + & + & M \\
\hline MM2 & + & + & + & + & + & + & ND \\
\hline Healthy & - & - & - & - & - & - & 0 \\
\hline
\end{tabular}

${ }^{\text {a }}$ Data indicated in this table were from 30 tests of each procedure used in the experiment

${ }^{\mathrm{b}} \mathrm{S}=$ stunting and/or decline effects in infected sweet orange on sour orange rootstock, $\mathrm{M}=$ no symptoms in infected sweet orange on sour orange rootstock, $\mathrm{ND}=$ not determined, and $0=$ no reaction.

with PBST buffer, a dark orange nonspecific background reaction was observed in ISIA. When PCA 1212 and MAb MCA13 were diluted with PSBT-B and the sections were washed with PBST-PVP and TTBS, the nonspecific background reaction was not present. MAb 17G11 worked well in ISIA, and no nonspecific background reaction was observed. Since the source of MAb 17G11 was undiluted cell culture fluid, it contained about $15 \%$ fetal bovine serum, which apparently blocked nonspecific reactions. PBST-B, used to dilute the other antibodies, contained 3\% fetal bovine serum, which apparently played an important role in blocking the nonspecific reactions.

A comparison of ISIA, DTBIA, and ILISA indicated that ISIA results were the same as those obtained with DTBIA (Fig. $1 \mathrm{G}$ and $\mathrm{H}$ ) and ELISA (Table 1).

Effects of storage of samples on ISIA. There were no obvious differences among the results from fresh versus stored samples at $4^{\circ} \mathrm{C}$ or $-20^{\circ} \mathrm{C}$ for $1,7,14,21$, and 30 days. All infected samples gave a positive result. Also, there were no differences between the fresh samples and samples stored at room temperature for 1 to 3 days.

\section{DISCUSSION}

Our results show that ISIA is a simple, rapid, and practical procedure for detecting CTV within tissues of infected plants directly and has several advantages for some applications. First, like DTBIA, it requires no extraction of samples, thus eliminating the need for homogenizers, or for tubes and containers to store extracts prior to testing. It overcomes the disadvantage of ISFA $(4,14)$ and easily, directly detects CTV within the tissues of infected plants with a light microscope. Furthermore, it can be completed in 2 to $4 \mathrm{~h}$, making it convenient when results are needed within 1 day. The principle of ISIA is similar to that of ELISA, Western blot, and DTBIA, except that the antigen is detected within tissues of the infected plants without trapping on a solid phase. Therefore, ISIA is a flexible procedure for researchers and diagnosti- cians. Generally, the incubation periods of the sections with specific antibodies or labeled secondary antibodies can be modified from $30 \mathrm{~min}$ to several hours, and the washing time may be 5 to $10 \mathrm{~min}$. The only specific equipment needed in the ISIA is a light microscope. With access to CTVspecific antibodies, any laboratory could conduct ISIA to detect CTV. The most unique advantage of ISIA is that it can be used to determine the three-dimensional distribution of CTV within the host. This may have important implications for crossprotection and pathogen-derived resistance studies. The ISIA procedure should also be suitable for detection of other viruses for which antibodies are available.

\section{ACKNOWLEDGMENTS}

We thank S. M. Garnsey for providing PCA 1212 and MAb MCA13.

\section{LITERATURE CITED}

1. Bar-Joseph, M., Garnsey, S. M., Gonsalves, D., Moscovitez, M., Purcifull, D. E., Clark, M. F., and Loebenstein, D. 1979. The use of enzyme-linked immunosorbent assay for the detection of citrus tristeza virus. Phytopathology 69:190-194.

2. Bar-Joseph, M., Garnsey, S. M., Gonsalves, D., and Purcifull, D. E. 1980. Detection of citrus tristeza virus. I. Enzyme-linked immunosorbent assay (ELISA) and SDS-immunodiffusion methods. Pages 1-8 in: Proc, Conf. IOCV, 8th. IOCV, Riverside, CA.

3. Brlansky, R. H., Garnsey, S. M., Lee, R. F., and Purcifull, D. E. 1984. Application of citrus tristeza virus antisera in labeled antibody, immunoelectron microscopical, and sodium dodecyl sulfate-immunodiffusion tests. Pages 337-342 in: Proc. Conf. IOCV, 9th. IOCV, Riverside, CA.

4. Brlansky, R. H., Lee, R. F., and Garnsey, S. M. 1988. In situ immunofluorecence for the detection of citrus tristeza virus inclusion bodies. Plant Dis. 72:1039-1041.

5. Cambra, M., Camarasa, E., Gorris, M. T., Gansey, S. M., and Carbonell, E. 1991. Comparison of different immunosorbent assays for citrus tristeza virus (CTV) using CTV-specific monoclonal and polyclonal antibodies. Pages 38-45 in: Proc. Conf. IOCV, 11th. IOCV, Riverside, $\mathrm{CA}$.

6. Garnsey, S. M., Gonsalves, D., and Purcifull, D. E. 1978. Rapid diagnosis of citrus tristeza virus infections by sodium dodecyl sulfateimmunodiffusion procedures. Phytopathology
68:88-95

7. Garnsey, S. M., Permar, T. A., Cambra, M. and Henderson, C. T. 1993. Direct tissue blot immunoassay (DTBIA) for detection of citrus tristeza virus (CTV). Pages 39-50 in: Proc. Conf. IOCV, 12th. IOCV, Riverside, CA.

8. Guerri, J., Moreno, P., and Lee, R. F. 1990 Identification of citrus tristeza virus strains by peptide maps of virion coat protein. Phytopathology 80:692-698.

9. Lee, R. F., Calvert, L. A., Nagel, J., and Hubbard, J. D. 1988. Citrus tristeza virus: Characterization of coat proteins. Phytopathology 78:1221-1226.

10. Nikolaeva, O. V., Karasev, A. V., Garnsey, S. M., and Lee, R. F. 1998. Serological differentiation of the citrus tristeza virus isolates causing stem pitting in sweet orange. Plant Dis. 82:1276-1280.

11. Nikolaeva, O. V., Karasev, A. V., Gumpf, D. J., Lee, R. F., and Garnsey, S. M. 1995. Production of polyclonal antisera to the coat protein of citrus tristeza virus expressed in Escherichia coli: Application for immunodiagnosis. Phytopathology 85:691-694.

12. Pappu, H. R., Pappu, S. S., Lee, R. F., Cambra, M., Moreno, P., Garnsey, S. M., and Niblett, C. L. 1994. The molecular basis for the antigenic diversity of citrus tristeza virus: Implications for virus detection. Proc. Fla. State Hortic. Soc. 107:8-12

13. Permar, T. A., Garnsey, S. M., Gumpf, D. J., and Lee, R. F. 1990. A monoclonal antibody that discriminates strains of citrus tristeza virus. Phytopathology 80:224-228.

14. Rocha-Pena, M., and Lee, R. F. 1991. Serological technique for detection of citrus tristeza virus. J. Virol. Methods 34:311-331.

15. Rocha-Pena, M. A., Lee, R. F., and Niblett, C. L. 1991. Development of a dot-immunobinding assay for detection of citrus tristeza virus. J. Virol. Methods 34:297-309.

16. Rocha-Pena, M. A., Lee, R. F., Permar, T. A., Yokomi, R. K., and Garnsey, S. M. 1991. Use of enzyme-linked immunosorbent and dotimmunobinding assay to evaluate two mild strains cross protection experiments after challenge with a severe citrus tristeza virus isolate. Pages 93-102 in: Proc. Conf. IOCV, 11th. IOCV, Riverside, CA.

17. Rosner, A., Lee, R. F., and Bar-Joseph, M 1986. Differential hybridization with cloned cDNA sequences for detecting a specific isolate of citrus tristeza virus. Phytopatholgy 76:820-824.

18. Vela, C., Cambra, M., Sanz, A., and Moreno, P. 1988. Use of specific monoclonal antibodies for diagnosis of citrus tristeza virus. Pages 55-61 in: Proc. Conf. IOCV, 10th. IOCV, Riverside, CA 